\title{
Development of Electronic Learning Media Based 3D Pageflip on Subject Matter of Photosynthetis in Plant Physiology Course
}

\section{Pengembangan Media Pembelajaran Elektronik Berbasis 3D Page Flip Pada Materi Fotosintesis Mata Kuliah Fisiologi Tumbuhan}

\author{
Upik Yelianti $^{1)}$, Muswita ${ }^{2)}$ M.E.,Sanjaya ${ }^{2)}$ \\ E-mail: upik.yelianti@unja.ac.id \\ ${ }^{1,2,3)}$ Staf Pengajar Prodi Pendidikan Biologi Jurusan PMIPA FKIP Universitas Jambi \\ Jl. Raya Jambi - Muaro Bulian km 15 Mendalo Indah Jaluko 36361 Hp. 08126747058
}

\begin{abstract}
The aim of this research is to develop the electronic learning media on the subject matter Plant Physiology based 3D pageflip. The $3 \mathrm{D}$ Pageflip is the software that can display the learning material, like: power point, text, pictures, photos, animation, student's worksheet and videos are integrated in one packaging. This research was designed in ADDIE's model which have five steps, namely: Analyze, Design, Develop, Implement, and Evaluate. This media was validated by design expert and content expert. The qualitative data from expert suggession used to revise this media, while the qualitative data got from the student's response to this media. This media was validated by design expert twice and got the last score about 44 (91.67\%) with very good criteria. Then, the media also validated by content expert and obtanied the score about $36(80 \%)$ with very good criteria. After validated, the electronic learning media trial to the biology student for the small group test with 9 students as a repondent and obtained the score about 48.87 with very good criteria, while the big group trial test with 15 student as a respondent, got the score about 49.87 with very good criteria. In conclussion, this electronic learning media on subject matter Photosynthesis for Plant Physiology course is very good to use in classroom and also individually.
\end{abstract}

Keywords: electronic media, 3D pageflip, photosynthesis, plant physiology

\begin{abstract}
Abstrak. Penelitian ini bertujuan untuk mengembangkan media pembelajaran elektronik berbasis 3D Pageflip pada materi fotosintesis mata kuliah Fisiologi Tumbuhan. 3D pageflip ini merupakan software yang dapat menyajikan perangkat pembelajaran seperti: PPT, teks, gambar, foto, LKPD, lagu, animasi, dan video yang terintegrasi dalam satu paket. Media ini dirancang dengan model ADDIE yang memiliki 5 tahapan, yaitu: Analisis, Desain, Develop, Implementasi, dan Evaluasi. Media elektronik ini divalidasi oleh ahli desain media dan ahli. Data kualitatif berupa saran diperoleh dari ahli desain dan ahli materi digunakan untuk merevisi media. Setelah media dinyatakan layak maka dilanjutkan dengan uji kelompok kecil dan besar untuk melihat repons mahasiswa biologi. Validasi desain media elektrnoik berbasis 3D pageflip dilakukan sebanyak 2 kali dan diperoleh skor akhir sebesar $44(91.67 \%)$ dengan kriteria sangat baik. Kemudian media divalidasi oleh ahli materi juga sebanyak 2 kali dan diperoleh skor akhir sebesar $36(80 \%)$ dengan kriteria sangat baik. Hasil ujicoba kelompok kecil dengan 9 orang mahasiswa pendidikan biologi sebagai responden dan diperoleh skor sebesar 48.87 dengan kriteria sangat baik/sangat setuju. Selanjutnya hasil ujicoba kelompok besar dengan jumlah mahasiswa sebanyak 15 orang diperoleh skor sebesar 49.87 dengan kriteria juga sangat baik. Dapat disimpulkan bahwa media pembelajaran elektronik berbasis 3D pageflip pada materi fotosintesis mata kuliah Fisiologi Tumbuhan sangat layak digunakan dalam pembelajaran di kelas maupun secara individu.
\end{abstract}

Kata kunci: media elektronik, 3D pageflip, fisiologi tumbuhan 


\section{PENDAHULUAN}

Pada abad ke-21 era global ditandai oleh terjadinya persaingan secara global di semua lini kehidupan. Perubahan yang sangat cepat setiap saat seringkali tak terduga dan terbukanya peluang baru bagi masyarakat untuk berkembang. Jika tidak mengikuti perubahan tersebut maka kita akan tertinggal. Kemajuan teknologi, big data dan Pembelajaran yang humanis merupakan ciri kemajuan pembelajaran saat ini (Sadikin, A, 2017). Oleh sebab itu peningkatan kualitas SDM sangat diperlukan agar mampu mengikuti setiap perubahan yang terjadi. Hal ini dapat dicapai melalui pendidikan yang berkualitas, yaitu proses pembelajaran yang berorientasi pada pencapaian kompetensi tingkat tinggi, mampu menyelsaikan masalah baik secara individu maupun dalam kerjasama.

Mahasiswa pada dasarnya merupakan subjek belajar yang dituntut untuk mampu mengelola dan melaksanakan tugas-tugas belajarnya secara mandiri, selama mengikuti kegiatan perkuliahan di perguruan tinggi. Hal ini telah ditegaskan dalam tujuan belajar mandiri sebagaimana yang dicanangkan pada sistem perkuliahan di perguruan tinggi yaitu, memposisikan mahasiswa sebagai penanggung jawab, pemegang kendali, pengambil keputusan atau pengambil inisiatif dalam memenuhi dan mencapai keberhasilan belajarnya sendiri tanpa harus bergantung dengan bantuan dari orang lain. Belajar mandiri penting bagi mahasiswa untuk meningkatkan motivasi, konsistensi, daya juang, dan rasa percaya diri (Sadikin, A, 2018). Kegiatan belajar mandiri yang ditujukan kepada mahasiswa bertujuan agar mahasiswa dapat bertanggungjawab penuh terhadap tugastugasnya. Dalam penguasaan materi perkuliahan, kegiatan belajar mandiri memberikan kesempatan kepada mahasiswa untuk menguasai materi secara mendalam sesuai dengan waktu yang dibutuhkan, serta kemampuan dan cara belajar yang dimiliki masing-masing individu. Untuk mencapai keberhasilannya dalam belajar, dibutuhkan komitmen dari mahasiswa untuk mencari hubungan konseptual antara pengetahuan yang dimilikinya dengan apa yang dipelajari di dalam perkuliahan.

Mata kuliah Fisiologi Tumbuhan merupakan salah satu mata kuliah yang bertujuan agar mahasiswa mampu memahami proses-proses fisiologis yang terjadi di dalam tubuh tumbuhan. Proses fisologis tersebut bersifat abstrak dan tidak terlihat oleh mata. misalnya pada materi Fotosintesis yang merupakan proses-proses biokimia yang terjadi pada tumbuhan yang melibatkan beberapa enzim Fotosintesis merupakan proses pembenatukan senyawa organik dalam bentuk glukosa (C6H12O6) dan Oksigen (O2) dari senyawa anorganik Karbondioksisa (CO2) dan air (H2O) dengan bantuan energi cahaya oleh organisme autotrof (Cambpell, 2014). Untuk memudahkan pemahaman tentang proses-proses fisiologis tersebut diperlukan suatu inovasi baru yaitu dengan menggunakan media pembelajaran.

Perkembangan teknologi informasi yang begitu pesat dalam pendidikan menuntut untuk berpacu untuk selalu menginovasi bahan ajar (Asyhar, R, 2012). Teknologi informasi memberikan 
peluang untuk berkreativitas dalam menyiapkan bahan ajar sehingga memudahkan dalam mentransfer ilmu dan teknologi kepada peserta didik. Selama ini pembelajaran mata kuliah Fisiologi Tumbuhan telah menggunakan media berbasis ICT, seperti media powerpoint, video, dan musik, maupun media online, akan tetapi belum terintegrasi menjadi satu kesatuan (beberapa file) sehingga memerlukan waktu untuk mengakses Media pembelajaran berbasis 3D Flip Fage dapat memberikan kemudahan dalam penyajian materi perkuliahan. Menurut Rasiman \& Pramasdyahsari, A.S., (2014) Flip Book Maker merupakan software yang dapat mengubah tampilan file pdf menjadi lebih menarik seperti layaknya sebuah buku. 3D PagerFlip Profesional adalah jenis software Flipbook untuk mengkonversi file PDF ke halaman membalik publikasi digital. Hal ini memungkinkan kita memasukkan video (yuotube, video), gambar, audio, grafik, slide, tombol, flash, hyperlink, hotspot dan objek multimedia lainnya ke halaman Flipbook. 3D PageFlip Profesional dapat memindahkan hyperlink, bookmark, daftar isi, dan orientasi teks dari file PDF asli, sehingga menjadi file buku yang menarik (Wijiyanto, 2005).

Hasil penelitian Zaharah, Yelianti. U \& Asra. R. (2017) dengan judul: Pengembangan Modul Elektronik dengan Pendekatan Saintifik pada Materi Sistem Peradaran Darah pada Manusia untuk Siswa Kelas VII SMP. Modul elektronik dikembangkan dengan menggunakan software 3D Pageflip Bookmaker. Hasil validasi ahli materi dan ahli media menunjukkan bahwa modul elektronik termasuk kategori sangat baik. Selanjutnya Imaduddin (2015) melakukan penelitian tentang : Pengembangan LKPD Digital Berbasis saintifik Approach pada materi Ekosistem untuk Siswa Kelas VII SMP. Penelitian ini juga menggunakan software 3D Pageflip Professional dan setelah divalidasi oleh ahli materi diperoleh skor $>85 \%$ dengan kategori Sangat Baik dan layak diujicobakan. Selanjutnya Hayati, S., Budi, A. S. dan Handuko. E. (2015) menggunakan media Flipbook untuk meningkatkan proses dan hasil belajar peserta didik. Akan tetapi, belum ada informasi tentang pengembangan media elektronik berbasis 3D Pageflip pada mata kuliah Fisiologi Tumbuhan. Melalui penelitian pengembangan ini diharapkan dapat memudahkan dosen dalam mentransfer ilmu pengetahuan khususnya pada mata kuliah Fisiologi Tumbuhan, sehingga materi pembelajaran terutama yang bersifat abstrak dapat dengan mudah dipahami oleh mahasiswa baik dalam pembelajaran di kelas maupun secara individu.

Penenelitian ini bertujuan untuk mengembangkan media pembelajaran elektronik berbasisi3D Pageflip pada materi Fisiologi Tumbuhan. Media ini dapat menyajikan perangkat pembelaran seperti teks, gambar, foto, animasi, video, dan lagu dalam satu kesatuan dalam bentuk buku, sehingga menarik, mudah dibawa, tidak berat karena paperless, serta dapat dibaca dimana saja dan kapan saja. Penelitian ini bertujuan untuk (a) Mengembangkan media pembelajaran elektronik berbasis 3D Pageflip pada mata kuliah Fisiologi Tumbuhan. (b) Mengetahui kelayakan media pembelajaran elektronik berbasis 3D Pageflip pada mata kuliah Fisiologi Tumbuhan . (c) 
Mengetahui respon mahasiswa terhadap produk media pembelajaran elektronik berbasis 3D Pageflip pada mata kuliah Fisiologi Tumbuhan.

\section{METODOLOGI}

\section{1). Jenis Penelitian}

Penelitian ini merupakan penelitian pengembangan (Research and development: R \& D) dengan menggunakan model pengembangan ADDIE (Lee \& Owen, 2004). Model pengembangan ADDIE terdiri dari 5 tahapan, yaitu: Analisis (Analyze), Desain (Design), Pengembangan (Developt), Implementasi (Implement) dan Evaluasi (Evaluate).

\section{2). Subjek dan Tempat Pelaksanaan Penelitian}

Penelitian ini dilaksanakan pada Program Studi Pendidikan Biologi Fakultas Keguruan dan Ilmu Pendidikan Universitas Jambi. Subjek penelitian adalah mahasiswa Program Pendidikan Biologi semester V Tahun Akademik 2017.. Alur dan diagram prosedur penelitian adalah sebagai berikut:

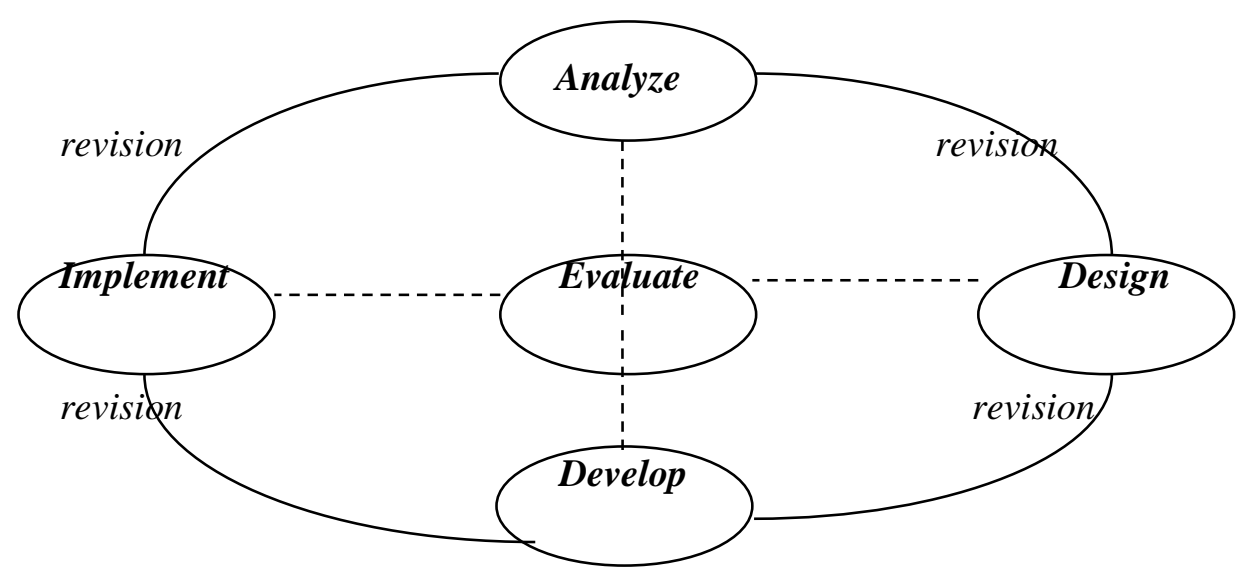

Gambar 1. Siklus Desain Model ADDIE

3). Tahapan Penelitian: Penelitian ini dirancang dengan mengikuti prosedur dan tahapan yang mengacu pada model pengembangan ADDIE. Tahapan dalam penelitian ini adalah:

a. Tahap Analisis: Tahap ini merupakan tahap awal dalam mengembangkan media pembelajaran berbasis 3D Page Flip. Pada tahap ini diawali dengan menganalisis masalah yang terjadi selama perkuliahan, menganalisis analisis media yang digunakan, dan materi yang menurut mahasiswa bersifat abstrak.

b. Tahap Desain: Pada tahap ini, dimulai merancang dan membuat prototipe produk berdasarkan data yang diperoleh dari observasi awal. Pembuatan produk berupa media pembelajaran berbasis 3D Page Flip pada materi Fotosintesis dilakukan dengan membuat berbagai materi ajar berdasarkan Silabus dan RPS serta alat evaluasi. 
c. Tahap Pengembangan; Pada tahap ini, protipe produk berupa media pembelajaran berbasis 3D Flip fage yang telah dikembangkan divalidasi oleh: ahli media, dan ahli materi. Produk direvisi sesuai masukan dan saran dari para ahli dan dinyatakan layak untuk diujicobakan.

d. Tahap Implementasi: Pada tahap ini, produk yang telah dinyatak layak oleh para ahli akan diujicoba di lapangan. Implementasi dilakukan pada kelompok kecil dan kelompok besar. Ujicoba kelompok kecil dengan subjek ujicoba adalah mahasiswa Pendidikan Biologi semester V yang berjumlah 9 orang yang terdiri dari berbagai kepintaran: Tinggi, Sedang dan Rendah (berdasarkan nilai akhir aspek kognitif). Subjek penelitian ini akan memberikan tanggapan terhadap produk yang sudah dikembangkan dengan jalan mengisi angket. Tanggapan mahasiswa menjadi pertimbangan peneliti untuk merevisi produk media pembelajaran elektronik. Selanjutnya adalah tahap ujicoba kelompok besar yang meibatkan 15 orang mahasiswa Prodi Pendidikan Biologi. Tahapannya sama seperti pada ujicoba kelompok kecil. Setelah subjek ujicoba diberikan media elektronik ini, tahap selanjutnya diberikan angket untuk melihat tanggapan mahasiswa mengenai perangkat pembelajaran.

e. Tahap Evaluasi: Tahap evaluasi merupakan tahap akhir setelah dilakukan ujicoba produk di lapangan. Saran dan respon dari mahasiswa menjadi pertimbangan untuk melakukan revisi pada produk sehingga layak untuk digunakan. Tahap evaluasi juga dilakukan pada setiap tahapan dalam penelitian ini.

4). Instrumen Penelitian : pada penelitian ini menggunakan instrumen sebagai beriukut:

a. Angket validasi ahli: Angket validasi ahli merupakan angket semi terbuka yang diberikan pada ahli media dan ahli materi saat uji validitas prototipe produk. Angket ini menggunakan skala likert dengan skala 1-4 (1: Sangat Tidak baik, 2: Tidak Baik, 3: Baik, dan 4: Sangat Baik). Pada angket ini juga dilengkapi dengan kolom saran di bawahnya sehingga para ahli dapat menuliskan tanggapan, kritik dan saran untuk perbaikan media elektronik 3D PageFlip.

b. Angket tanggapan mahasiswa: Angket respon mahasiswa juga merupakan angket semi terbuka yang diberikan pada subjek penelitian pada tahap ujicoba kelompok kecil maupun besar. Angket ini juga menggunakan skala likert (1-4) dengan kriteria yang sama dengan angket validasi dan juga dilengkapi dengan pendapatnya. Tanggapan mahasiswa menjadi pertimbangan untuk merevisi produk media pembelajaran elektronik 3D PageFlip.

\subsection{Teknik Pengumpulan Data}

Teknik pengumpulan data dilakukan dengan berbagai cara, yaitu: mahasiswa sebagai subjek ujicoba produk media elektronik 3D Page Flip, 1). Observasi: untuk menganalisis permasalahan yang dihadapi mahasiswa dan mengetahui kebutuhan mahasiswa, 2). 
Wawancara: dilakukan untuk mengetahui kebutuhan mahasiswa dan dosen dalam pembelajaran mata kuliah Fisologi Tumbuhan, dan 3). Penyebaran angket: untuk mengetahui kelayakan produk media elektronik 3D Pageflip yang sudah dikembangkan divalidasi oleh validator (ahli materi dan ahli desain media).

5). Analisis Data: Data dianalisis secara deskriptif kualititatif dan deskriptif kuantitatif. Data hasil validasi dari ahli desain dan ahli materi diolah secara deskriptif kualitatif yang bertujuan untuk melihat kelayakan produk yang sudah dikembangkan. Data diperoleh melalui angket tertutup dengan menggunakan skala Likert kemudian dianalisis dengan menggunakan rating scale. Uji dilakukan untuk mengetahui kevalidan dari produk yang sudah dikembangkan. Tingkat kevalidan dapat dihitung dengan mempertimbangkan jumlah kategori (1-4), jumlah item deskriptor yang dinilai, dan jumlah responden. Selanjutnya dibuat tabel kriteria tingkat validasi ahli materi maupun ahli desain (Harlis \& Budiarti, R.S. (2017).

1). Jumlah soal untuk validasi desain adalah 12 , maka perhitungannya adalah sebagai berikut:

Kategori penilaian: 4 dan jumlah validator: 1 .

Skor terendah: 1 x $12 \times 1=12$

Skor tertinggi: $4 \times 12 \times 1=48$

$\begin{array}{rcc}\text { Skor tertinggi }- \text { skor terendah } & 48-12 & 36 \\ \text { Rentang nilai: }-\mathbf{-} \text { Kategori penilaian } & 4 & 4\end{array}$

Tabel 3.1 Kevalidan Media Pembelajaran Elektronik oleh Ahli Desain

\begin{tabular}{|l|c|c|c|}
\hline No. & Rentang Nilai & Persentase $(\%)$ & Kriteria \\
\hline 1. & $39.00-48.00$ & $81.25-100.00$ & Sangat Baik \\
\hline 2. & $30.00-38.99$ & $62.50-81.24$ & Baik \\
\hline 3. & $21.00-29.99$ & $43.75-62.49$ & Tidak Baik \\
\hline 4. & $12.00-20.99$ & $25.00-43.74$ & Sangat Tidak baik \\
\hline
\end{tabular}

2). Jumlah soal untuk validasi materi adalah 10 , maka perhitungannya adalah sebagai berikut:

Kategori penilaian: 4 dan jumlah validator: 1 .

Skor terendah: $1 \times 10 \times 1=10$

Skor tertinggi: $4 \times 10 \times 1=40$

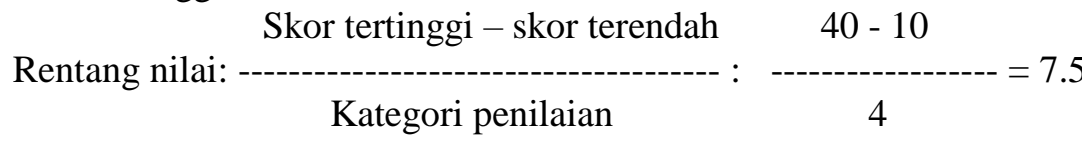

Tabel 3.2 Kevalidan Media Pembelajaran Elektronik oleh Ahli Materi

\begin{tabular}{|l|c|c|c|}
\hline No. & Rentang Nilai & Persentase $(\%)$ & Kriteria \\
\hline 1. & $32.50-40.00$ & $81.25-100.00$ & Sangat Baik \\
\hline 2. & $25.00-32.49$ & $62.50-81.24$ & Baik \\
\hline 3. & $17.50-24.99$ & $43.75-62.49$ & Tidak Baik \\
\hline 4. & $10.00-17.49$ & $25.00-43.74$ & Sangat Tidak baik \\
\hline
\end{tabular}

3). Jumlah soal untuk subjek ujicoba kelompok kecil adalah 14, maka perhitungannya adalah:

Kategori penilaian: 4 dan jumlah validator: 1 .

Skor terendah: $1 \times 14 \times 1=14$

Skor tertinggi: $4 \times 14 \times 1=56$ 


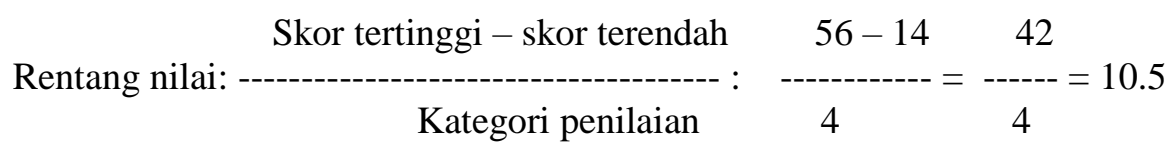

Tabel 3.3 Kriteria respon mahasiswa terhadap media pembelajaran elektronik 3D Pageflip

\begin{tabular}{|l|c|c|c|}
\hline No. & Rentang Nilai & Persentase $(\%)$ & Kriteria \\
\hline 1. & $45.50-56.00$ & $81.25-100.00$ & Sangat Setuju/sangat layak \\
\hline 2. & $35.00-45.49$ & $62.50-81.24$ & Setuju /layak \\
\hline 3. & $24.50-34.99$ & $43.75-62.49$ & Tidak Setuju/tidak layak \\
\hline 4. & $14.00-24.49$ & $25.00-43.74$ & $\begin{array}{c}\text { Sangat Tidak Setuju/ sangat tidak } \\
\text { layak }\end{array}$ \\
\hline
\end{tabular}

\section{HASIL PENELITIAN DAN PEMBAHASAN}

\subsection{Hasil Penelitian}

Penelitian pengembangan media pembelajaran elektronik berbasis 3D Pageflip untuk mata kuliah Fisiologi Tumbuhan pada materi Fotosintesis telah dilakukan dengan langkah-langkah sesuai dengan model ADDIE. Berikut hasil penelitian dari tahap analisis, desain, develop, implementasi dan evaluasi. Hasil dari tahap analisis yaitu $75 \%$ mahasiswa terlihat kebingungan memahami tahapan dari proses fisiologis yang terjadi dalam tubuh tumbuhan tersebut. Materi mata kuliah Fisiologi Tumbuhan ini antara lain: 1). Penyerapan Air dan Unsur hara, 2). Proses Fotosintesis, dan 3). Proses Respirasi (Salisbury, F.B., \& Cleon W. Ross, 1995). Ketiga proses ini membutuhkan pemahaman yang mendalam. Selama ini pembelajaran sudah diarahkan pada penggunaan media berbasis ICT dengan menggunakan media power point dan video yang berhubungan dengan materi tersebut. Akan tetapi masih terpisah antara teks, video musik, suara, dan animasi, sehingga membuthkan file yang banyak. Penyajian Flip fage berupa buku yang bisa dibalik sesuai dengan halaman yang diinginkan dan dapat juga diintegrasikan dengan foto dan video serta musik. Jika ditinjau dari segi mahasiswa sebagai subjek pebelajar, maka jenjang perkuliahan mahasiswa memiliki rasa ingin tahu (curiousity) yang tinggi sehingga mudah mengoperasikan berbagai software.

Pada tahap desain, hasil yang didapat berupa bentuk protipe produk yang telah dikembangkan. Dalam membuat desain peneliti mengumpulkan data dari berbagai sumber literature yang relevan. Rancangan awal yang telah disusun cover, judul, kata pengantar, daftar isi, silabus dan petunjuk penggunaan media, SK, KD, Indikator yang akan dicapai, terdapat tujuan yang akan dicapai, kerangka peta konsep materi, landasan teori, tujuannya supaya mahasiswa dapat memperoleh pengetahuan dan informasi mengenai materi fotosintesis, soal, umpan balik, dan tindak lanjut. Adapun bentuk desain dari produk yang dikembangkan sebagai berikut: 

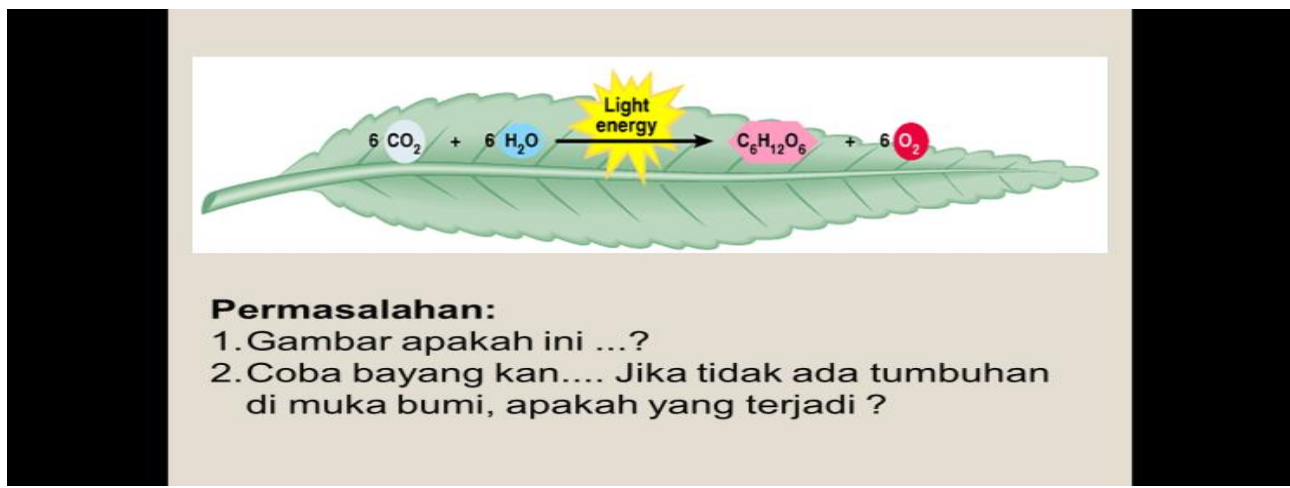

Gambar 1: Desain Produk 3D Page Flip Materi Fotosintesis
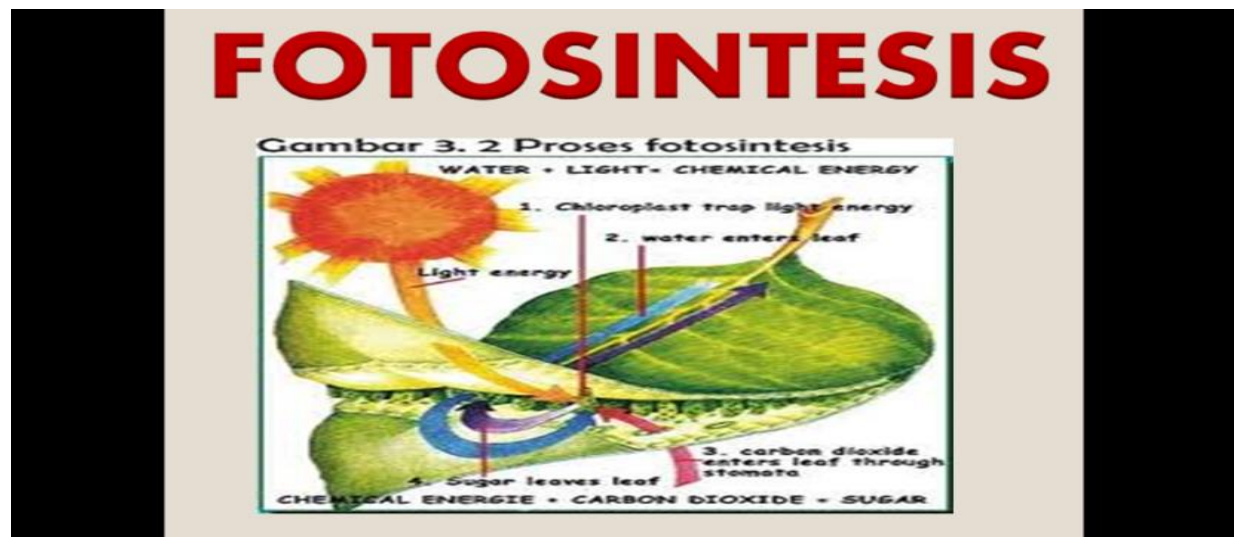

Gambar 2: Tampilan Awal 3D Page Flip Materi Fotosintesis

Pada tahap pengembangan dalam penelitian ini yaitu melakukan validasi uji produk secara konseptual. Validasi yang dilakukan yait validasi desain dan validasi materi. Validasi desain dilakukan oleh Ibu Desfaur Natalia, M. Pd dan validasi materi dilakukan oleh Ibu Serly, M. Pd. Hasil validasi oleh ahli desain media pembelajaran elektronik berbasis 3D Pageflip disajikan pada Tabel 3.1 berikut ini:

Tabel 3.1 Hasil validasi ahli desain media elektronik berbasis 3D Pageflip tahap I

\begin{tabular}{|l|l|c|l|}
\hline No & \multicolumn{1}{|c|}{ Pernyataan } & Skor & \multicolumn{1}{|c|}{ Komentar dan saran } \\
\hline 1. & $\begin{array}{l}\text { Tampilan awal media pembelajaran elektronik } \\
\text { berbasis 3D Pageflip }\end{array}$ & 3 & Tidak ada perbaikan \\
\hline 2. & $\begin{array}{l}\text { Desain media pembelajaran elektronik berbasis 3D } \\
\text { Pageflip }\end{array}$ & 2 & $\begin{array}{l}\text { Perbaiki desain media sehingga } \\
\text { lebih rapi }\end{array}$ \\
\hline 3. & $\begin{array}{l}\text { Kerapian media pembelajaran elektronik berbasis 3D } \\
\text { Pageflip }\end{array}$ & 2 & Perbaiki tata letak teks gambar \\
\hline 4. & $\begin{array}{l}\text { Ketepatan pemilihan warna background media } \\
\text { pembelajaran elektronik berbasis 3D Pageflip }\end{array}$ & 3 & Tidak ada perbaikan \\
\hline 5. & Ketepatan memilih warna dan ukuran huruf pada teks & 3 & Tidak ada perbaikan \\
\hline 6. & $\begin{array}{l}\text { Ketepatan memilih jenis huruf yang terdapat dalam } \\
\text { teks }\end{array}$ & 3 & Tidak ada perbaikan \\
\hline
\end{tabular}




\begin{tabular}{|l|l|c|l|}
\hline 7. & $\begin{array}{l}\text { Penggunaan musik pendukung pada media } \\
\text { pembelajaran elektronik berbasis 3D Pageflip }\end{array}$ & 3 & Tidak ada perbaikan \\
\hline 8. & $\begin{array}{l}\text { Ketepatan memilih gambar yang digunakan dalam } \\
\text { media pembelajaran elektronik berbasis 3D Pageflip }\end{array}$ & 2 & $\begin{array}{l}\text { Gambar diganti dengan yang } \\
\text { lebih jelas. }\end{array}$ \\
\hline 9. & $\begin{array}{l}\text { Ketepatan memilih video yang digunakan dalam } \\
\text { media pembelajaran elektronik berbasis 3D Pageflip }\end{array}$ & 3 & Tidak ada perbaikan \\
\hline 10 & $\begin{array}{l}\text { Kesederhanaan media pembelajaran elektronik } \\
\text { berbasis 3D Pageflip }\end{array}$ & 4 & Tidak ada perbaikan \\
\hline 11 & Kemudahan pengoperasian & 4 & Tidak ada perbaikan \\
\hline 12 & $\begin{array}{l}\text { Program berjalan dengan baik pada komputer yang } \\
\text { digunakan. }\end{array}$ & 4 & Tidak ada perbaikan \\
\hline \multicolumn{2}{|c|}{ Jumlah skor / Persentase (\%) } & $36 / 75$ & $\begin{array}{l}\text { Media ini perlu perbaikan pada } \\
\text { bagian desain dan kerapiannya. }\end{array}$ \\
\hline
\end{tabular}

BerdasarkanTabel 3.1 terlihat bahwa hasil validasi dari ahli desain media mendapat skor sebesar 36 (75\%) dengan kriteria baik, namun karena ada beberapa item memiliki skor yang rendah maka disarankan untuk memperbaiki seperti: tata letak antara gambar dan teks. Di samping itu juga disarankan untuk merapikan media dan mengganti gambar dengan yang lebih jelas. Selanjutnya media direvisi sesuai dengan saran validator desain dan divalidasi lagi untuk kedua kalinya. Hasil validasi dari ahli desain pada tahap II disajikan pada Tabel 3.2 berikut ini:

Tabel 3.2 Hasil Validasi media elektronik berbasis 3D Pageflip oleh Ahli Desain Tahap II

\begin{tabular}{|l|l|c|l|}
\hline No & \multicolumn{1}{|c|}{ Pernyataan } & Skor & \multicolumn{1}{|c|}{ Komentar dan saran } \\
\hline 1. & $\begin{array}{l}\text { Tampilan awal media pembelajaran elektronik berbasis } \\
\text { 3D Pageflip }\end{array}$ & 3 & Tidak ada perbaikan \\
\hline 2. & $\begin{array}{l}\text { Desain media pembelajaran elektronik berbasis 3D } \\
\text { Pageflip }\end{array}$ & 3 & $\begin{array}{l}\text { Perbaiki desain media } \\
\text { sehingga lebih rapi }\end{array}$ \\
\hline 3. & $\begin{array}{l}\text { Kerapian media pembelajaran elektronik berbasis 3D } \\
\text { Pageflip }\end{array}$ & 3 & $\begin{array}{l}\text { Perbaiki tata letak teks } \\
\text { gambar }\end{array}$ \\
\hline 4. & $\begin{array}{l}\text { Ketepatan pemilihan warna background media } \\
\text { pembelajaran elektronik berbasis 3D Pageflip }\end{array}$ & 4 & Tidak ada perbaikan \\
\hline 5. & Ketepatan memilih warna dan ukuran huruf pada teks & 4 & Tidak ada perbaikan \\
\hline 6. & Ketepatan memilih jenis huruf yang terdapat dalam teks & 4 & Tidak ada perbaikan \\
\hline 7. & $\begin{array}{l}\text { Penggunaan musik pendukung pada media pembelajaran } \\
\text { elektronik berbasis 3D Pageflip }\end{array}$ & 4 & Tidak ada perbaikan \\
\hline 8. & $\begin{array}{l}\text { Ketepatan memilih gambar yang digunakan dalam media } \\
\text { pembelajaran elektronik berbasis 3D Pageflip }\end{array}$ & 3 & Tidak ada perbaikan \\
\hline 9. & $\begin{array}{l}\text { Ketepatan memilih video yang digunakan dalam media } \\
\text { pembelajaran elektronik berbasis 3D Pageflip }\end{array}$ & 4 & Tidak ada perbaikan \\
\hline 10 & $\begin{array}{l}\text { Kesederhanaan media pembelajaran elektronik berbasis } \\
\text { 3D Pageflip }\end{array}$ & 4 & Tidak ada perbaikan \\
\hline 11 & Kemudahan pengoperasian & 4 & Tidak ada perbaikan \\
\hline 12 & $\begin{array}{l}\text { Program berjalan dengan baik pada komputer yang } \\
\text { digunakan. }\end{array}$ & 4 & Tidak ada perbaikan \\
\hline & \multicolumn{1}{|c|}{ Jumlah skor / Persentase (\%) } & $44 / 91.67$ & $\begin{array}{l}\text { Media ini sudah sangat baik } \\
\text { dan layak diujicobakan. }\end{array}$ \\
\hline
\end{tabular}

Setelah dilakukan perbaikan, selanjutnya media kembali divalidasi oleh ahli desain dan memperoleh skor sebesar 44 (91.67\%) dengan kriteria sangat baik. Media pembelajaran elektronik mata kuliah Fisiologi Tumbuhan berbasis 3D Pageflip siap untuk diujicobakan pada subjek ujicoba 
kelompok kecil. Hasil validasi media elektronik mata kuliah Fisiologi Tumbuhan materi Fotosintesis oleh ahli materi dapat dilihat pada Tabel 3.3 berikut ini:

Tabel 3.3 Hasil Validasi media elektronik berbasis 3D Pageflip oleh Ahli Materi

\begin{tabular}{|c|c|c|c|}
\hline No & $\begin{array}{l}\text { Pernyataan } \\
\end{array}$ & Skor & Komentar dan saran \\
\hline 1. & $\begin{array}{l}\text { Kesesuaian materi yang disajikan dengan SAP mata kuliah } \\
\text { Fisiologi Tumbuhan }\end{array}$ & 4 & Tidak ada perbaikan \\
\hline 2. & $\begin{array}{l}\text { Kesesuaian animasi yang ditampilkan dengan materi yang } \\
\text { disajikan dalam media 3D Pageflip. }\end{array}$ & 3 & Tidak ada perbaikan \\
\hline 3. & Materi mempunyai konsep yang benar dan tepat & 4 & Tidak ada perbaikan \\
\hline 4. & $\begin{array}{lllll}\begin{array}{l}\text { Kesesuaian gambar yang disajikan dengan materi } \\
\text { perkuliahan }\end{array} & & & \\
\end{array}$ & 4 & Tidak ada perbaikan \\
\hline 5. & Kesesuaian video yang disajikan dengan materi perkuliahan. & 3 & Tidak ada perbaikan \\
\hline 6 & Susunan penyajian materi sudah sistematis & 4 & Tidak ada perbaikan \\
\hline 7. & Kemudahan dalam pemahaman materi & 4 & Tidak ada perbaikan \\
\hline 8. & Media ini memungkinkan mahasiswa untuk belajar mandiri & 4 & Tidak ada perbaikan \\
\hline 9. & $\begin{array}{l}\text { Media pembelajaran elektronik 3d Pageflip ini bersifat } \\
\text { interaktif. }\end{array}$ & 3 & Tidak ada perbaikan \\
\hline 10. & Bahasa yang digunakan mudah dimengerti & 3 & Tidak ada perbaikan \\
\hline \multicolumn{2}{|r|}{ Jumlah skor / Persentase (\%) } & $36 / 90 \%$ & \multirow{2}{*}{$\begin{array}{l}\text { Media ini sangat baik } \\
\text { dan layak untuk } \\
\text { diujicoba. }\end{array}$} \\
\hline & Kriteria & $\begin{array}{l}\text { Sangat } \\
\text { Baik }\end{array}$ & \\
\hline
\end{tabular}

Hasil validasi dari ahli materi pada tahap I diperbaiki kemudian divalidasi lagi pada tahap II diperoleh nilai sebesar 36 (90\%) dengan kategori sangat baik. Selanjutnya media elektronik mata kuliah Fisiologi Tumbuhan dapat diujicobakan pada subjek ujicoba kelompok kecil dan kelomppok besar. Tahap implementasi Pada tahap ini, produk yang telah dinyatakan layak oleh para ahli diujicoba di lapangan. Implementasi dilakukan pada kelompok kecil dan kelompok besar. Ujicoba kelompok kecil dengan subjek ujicoba adalah mahasiswa Pendidikan Biologi semester V yang berjumlah 9 orang. Subjek penelitian ini memberikan tanggapan terhadap produk yang sudah dikembangkan dengan jalan mengisi angket. Tanggapan mahasiswa menjadi pertimbangan untuk merevisi produk media pembelajaran elektronik. Hasil ujicoba kelompok kecil media elektronik berbasis 3D Pageflip disajikan pada Tabel 3.4 berikut ini:

Tabel 3.4 Hasil Angket Mahasiswa pada Ujicoba Kelompok Kecil

\begin{tabular}{|c|c|c|c|c|c|c|c|c|c|c|c|c|c|c|c|c|}
\hline \multirow{2}{*}{$\begin{array}{c}\text { No } \\
\text { responden }\end{array}$} & \multicolumn{14}{|c|}{ Skor per Item } & Total & $\%$ \\
\hline & 1 & 2 & 3 & 4 & 5 & 6 & 7 & 8 & 9 & 10 & 11 & 12 & 13 & 14 & & \\
\hline 1 & 3 & 4 & 4 & 3 & 3 & 3 & 4 & 3 & 3 & 3 & 3 & 4 & 3 & 3 & 46 & 82 \\
\hline 2 & 3 & 3 & 4 & 3 & 4 & 3 & 3 & 3 & 3 & 3 & 3 & 3 & 4 & 4 & 46 & 82 \\
\hline 3 & 4 & 3 & 3 & 3 & 4 & 3 & 4 & 4 & 3 & 3 & 3 & 4 & 4 & 3 & 48 & 85 \\
\hline 4 & 4 & 3 & 4 & 4 & 4 & 4 & 4 & 4 & 4 & 4 & 3 & 4 & 4 & 4 & 54 & 96 \\
\hline 5 & 4 & 3 & 4 & 3 & 4 & 3 & 3 & 4 & 4 & 3 & 3 & 3 & 4 & 4 & 49 & 87 \\
\hline 6 & 4 & 4 & 4 & 3 & 3 & 4 & 3 & 3 & 3 & 3 & 4 & 3 & 4 & 4 & 49 & 87 \\
\hline 7 & 4 & 3 & 4 & 4 & 4 & 3 & 4 & 3 & 4 & 3 & 3 & 4 & 3 & 4 & 50 & 89 \\
\hline 8 & 4 & 4 & 4 & 4 & 3 & 3 & 4 & 4 & 4 & 4 & 3 & 4 & 4 & 4 & 53 & 94 \\
\hline 9 & 3 & 3 & 3 & 3 & 4 & 4 & 4 & 3 & 3 & 3 & 3 & 3 & 3 & 3 & 45 & 80 \\
\hline Total & 33 & 32 & 37 & 34 & 38 & 36 & 40 & 39 & 40 & 39 & 39 & 44 & 46 & 47 & 440 & \\
\hline Rata-rata & 3,6 & 3,5 & 4,1 & 3,7 & 4,2 & 4.0 & 4,4 & 4,3 & 4,4 & 4,3 & 4,3 & 4,8 & 5,1 & 5,2 & 48,8 & 86,87 \\
\hline Kriteria & $\mathbf{L}$ & $\mathbf{L}$ & $\mathbf{L}$ & $\mathbf{L}$ & $\mathbf{L}$ & $\mathbf{L}$ & $\mathbf{L}$ & $\mathbf{L}$ & $\mathbf{L}$ & $\mathbf{L}$ & $\mathbf{L}$ & $\mathbf{L}$ & $\mathbf{L}$ & $\mathbf{L}$ & Sangat & Layak \\
\hline
\end{tabular}

Ket: $\mathrm{L}$ = Layak 
Berdasarkan Tabel 3.4 diketahui bahwa secara keseluruhan mahasiswa sudah menganggap media elektronik sangat menarik, meyenangkan, mudah mengoperasikannya, terdapat animasi dan video serta suara yang menunjang dalam memahami materi fotosintesis. Hal ini terlihat dari kriteria semua item soal yang rata-rata memiliki kriteria layak dengan rata-rata skor per itemnya adalah 48,8 $(86,87 \%)$ dengan kriteria sangat layak untuk dijadikan media pembelajaran. Dengan baiknya respon mahasiswa pada ujicoba kelompok kecil, maka media elektronik 3D Pageflip sudah siap untuk diujikan pada kelompok yang lebih besar lagi.

Selanjutnya adalah tahap ujicoba kelompok besar yang melibatkan 15 orang mahasiswa Prodi Pendidikan Biologi. Tahapannya sama seperti pada ujicoba kelompok kecil. Setelah subjek ujicoba diberikan media elektronik ini, tahap selanjutnya diberikan angket untuk melihat tanggapan mahasiswa mengenai media pembelajaran elektronik berbasis 3D Pageflip. Hasil ujicoba kelompok besar adalah sebagai berikut:

Tabel 3.5 Hasil Angket Mahasiswa pada Ujicoba Kelompok Besar

\begin{tabular}{|c|c|c|c|c|c|c|c|c|c|c|c|c|c|c|c|c|}
\hline \multirow{2}{*}{$\begin{array}{c}\text { No } \\
\text { responden }\end{array}$} & \multicolumn{14}{|c|}{ Skor per Item } & \multirow{2}{*}{ Total } & \multirow{2}{*}{$\%$} \\
\hline & 1 & 2 & 3 & 4 & 5 & 6 & 7 & 8 & 9 & 10 & 11 & 12 & 13 & 14 & & \\
\hline 1 & 4 & 3 & 4 & 4 & 4 & 4 & 4 & 4 & 3 & 4 & 4 & 4 & 4 & 4 & 54 & 96.43 \\
\hline 2 & 4 & 4 & 4 & 3 & 3 & 4 & 4 & 3 & 3 & 4 & 3 & 4 & 4 & 4 & 51 & 91.07 \\
\hline 3 & 3 & 4 & 4 & 3 & 4 & 4 & 3 & 4 & 3 & 4 & 2 & 3 & 3 & 4 & 48 & 85.71 \\
\hline 4 & 3 & 4 & 4 & 3 & 4 & 4 & 4 & 4 & 4 & 3 & 3 & 4 & 4 & 4 & 52 & 92.86 \\
\hline 5 & 4 & 4 & 4 & 4 & 4 & 3 & 4 & 4 & 3 & 4 & 4 & 4 & 4 & 4 & 54 & 96.43 \\
\hline 6 & 4 & 3 & 3 & 3 & 3 & 3 & 3 & 3 & 4 & 3 & 3 & 2 & 3 & 3 & 43 & 76.79 \\
\hline 7 & 3 & 3 & 3 & 3 & 2 & 3 & 3 & 4 & 2 & 3 & 2 & 3 & 3 & 3 & 40 & 71.43 \\
\hline 8 & 4 & 4 & 4 & 4 & 3 & 3 & 3 & 3 & 3 & 3 & 3 & 4 & 4 & 4 & 49 & 87.50 \\
\hline 9 & 3 & 3 & 4 & 3 & 4 & 4 & 4 & 3 & 4 & 4 & 4 & 4 & 4 & 3 & 51 & 91.07 \\
\hline 10 & 3 & 3 & 3 & 4 & 3 & 3 & 3 & 3 & 4 & 3 & 3 & 3 & 4 & 4 & 46 & 82.14 \\
\hline 11 & 4 & 4 & 4 & 4 & 4 & 4 & 3 & 4 & 4 & 4 & 4 & 4 & 4 & 4 & 53 & 94.64 \\
\hline 12 & 4 & 4 & 3 & 4 & 4 & 3 & 4 & 3 & 4 & 3 & 4 & 4 & 4 & 4 & 51 & 91.07 \\
\hline 13 & 4 & 3 & 4 & 4 & 3 & 4 & 4 & 3 & 4 & 4 & 4 & 3 & 4 & 4 & 52 & 92.86 \\
\hline 14 & 3 & 4 & 4 & 4 & 4 & 3 & 3 & 4 & 4 & 4 & 4 & 4 & 4 & 4 & 53 & 94.64 \\
\hline 15 & 4 & 4 & 4 & 4 & 4 & 4 & 3 & 4 & 4 & 3 & 3 & 3 & 3 & 4 & 51 & 91.07 \\
\hline Total & 54 & 54 & 56 & 54 & 53 & 53 & 52 & 53 & 53 & 53 & 46 & 53 & 56 & 57 & 748 & 1335.71 \\
\hline Rata-rata & 3.6 & 3.6 & 3.7 & 3.6 & 3.5 & 3.5 & 3.5 & 3.5 & 3.5 & 3.5 & 3.1 & 3.5 & 3.7 & 3.8 & 49.87 & 89.05 \\
\hline Kriteria & $\mathrm{L}$ & $\mathrm{L}$ & $\mathrm{L}$ & $\mathrm{L}$ & $\mathrm{L}$ & $\mathrm{L}$ & $\mathrm{L}$ & $\mathrm{L}$ & $\mathrm{L}$ & $\mathrm{L}$ & $\mathrm{L}$ & $\mathrm{L}$ & $\mathrm{L}$ & $\mathrm{L}$ & Sang & t Layak \\
\hline
\end{tabular}

Keterangan: $\mathrm{L}=$ Layak $: \mathrm{SL}=$ Sangat Layak

Hasil ujicoba kelompok besar media pembelajaran elektronik berbasis 3D diperoleh skor sebesar 49.47 (89.05\%) dengan kriteria sangat layak. Hal ini berarti bahwa media pembelajaran elektronik ini sangat layak dijadikan sebagai media pembelajaran untuk mata kuliah Fisiologi Tumbuhan khususnya pada materi Fotosintesis untuk mahasiswa Biologi. Adapun produk akhir dari media yang dikembangkan. 


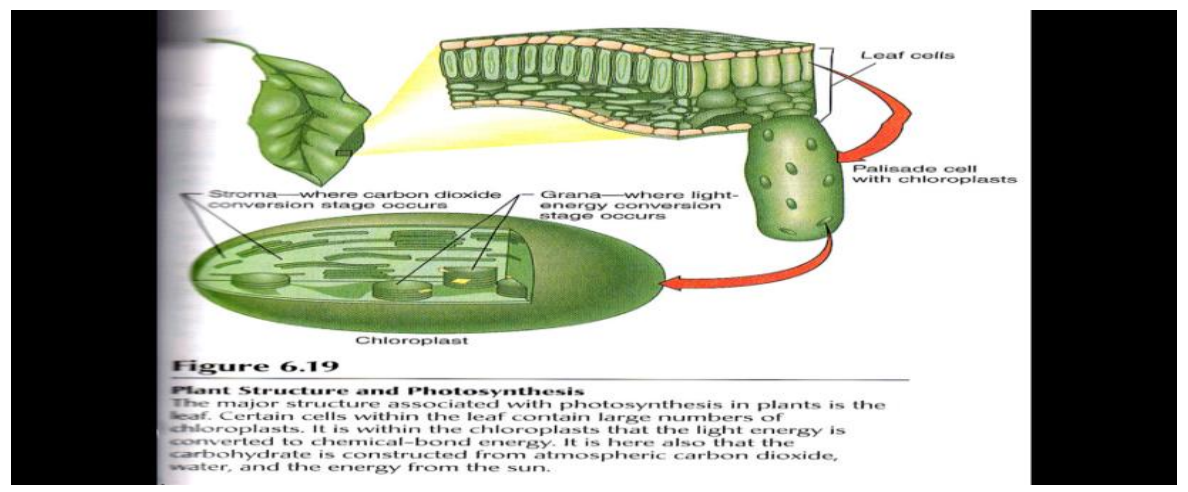

Gambar 3: Media 3D Page Flip Materi Fotosintesis

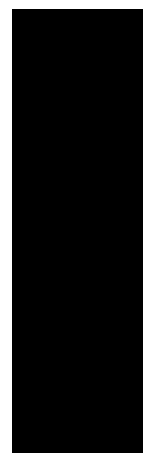

STANDAR KOMPETENSI

DAN

KOMPETENSI DASAR

- SK

Memahami pentingnya proses fotosintesis pada tumbuhan.

- KD

- Menjelaskan pengertian, manfaat dan organel dalam proses fotosintesis.

Menjelaskan tahapan - tahapan penting proses fotosintesis.

Menjelaskan faktor-faktor yang mempengaruhi proses fotosintesis.

Gambar 4: Media 3D Page Flip Materi Fotosintesis

\subsubsection{Tahap Evaluasi (Evaluate):}

Tahap evaluasi merupakan tahap akhir setelah dilakukan ujicoba produk di lapangan. Saran dan respon dari mahasiswa menjadi pertimbangan untuk melakukan revisi pada produk sehingga layak untuk digunakan. Tahap evaluasi juga dilakukan pada setiap tahapan dalam penelitian ini.

\section{SIMPULAN DAN PROSPEK}

\subsection{Kajian Produk yang telah Direvisi}

Berdasarkan hasil penelitian pengembangan dan pembahasan tentang media Elektronik berbasis 3D Mata Kuliah Fisiologi Tumbuhan pada Materi Fotosintesis Untuk Mahasiswa Pendidikan Biologi yang telah dikembangkan, maka ada beberapa hal yang dapat dikaji, yaitu:

a. Pengembangan media Elektronik berbasis 3D Pageflip mata kuliah Fisiologi Tumbuhan pada materi Fotosintesis untuk mahasiswa Pendidikan Biologi dilakukan dengan beberapa tahap, yaitu: menganalisis hambatan dan penyebabnya yang dialami oleh mahasiswa pendidikan biologi terhadap mata kuliah Fisiologi Tumbuhan dan melakukan proses pengumpulan materi yang disajikan pada media, mendesain media dan cara penggunaannya, melakukan validasi desain dan materi pembelajaran media kepada tim validator, merevisi produk berdasarkan hasil validasi dan saran tim validator, dan melakukan ujicoba produk pada kelompok kecil dan besar. 
b. Hasil validasi desain media dan ahli materi dari media elektronik berbasis 3D Pageflip mata kuliah Fisiologi Tumbuhan pada materi Fotosintesis dinyatakan sangat baik untuk digunakan dalam pembelajaran.

c. Tanggapan mahasiswa terhadap media elektronik berbasis 3D Pageflip mata kuliah Fisiologi Tumbuhan pada Materi Fotosintesis menyatakan sangat layak untuk dijadikan sebagai media pembelajaran untuk Pendidikan Biologi.

\subsection{Prospek}

Prospek dari pengembangan ini adalah sebagai berikut:

a. Media elektronik berbasis 3D Pageflip mata kuliah Fisiologi Tumbuhan pada materi Fotosintesis ini dapat dikembangkan lebih lanjut dengan desain yang lebih unik dan lebih menarik lagi.

b. Media Elektronik berbasis 3D Pageflip mata kuliah Fisiologi Tumbuhan pada materi Fotosintesis ini dapat dijadikan sebagai alternatif media pembelajaran bagi mahasiswa dalam mempelajari proses-proses biokimia yang terdapat pada materi Fotosintesis secara mandiri.

c. Selanjutnya diharapkan dapat mengembangkan media ini pada materi lain seperti penyerapan Air dan Unsur Hara, Respitasi dan Transpirasi dengan menggunakan media elektronik berbasis 3D Pageflip.

\section{DAFTAR RUJUKAN}

Asyhar, R. (2012). Kreatif mengembangkan media pembelajaran. Jakarta: GP Press.

Campbell. (2014). Biologi tenth edition jilid I. New York: Pearson Education..

Harlis \& Budiarti, R.S. (2017). Pengembangan bahan ajar praktikum dan instrumen penilaian berbasis keterampilan proses sains pada mata kuliah mikologi program studi pendidikan biologi universitas jambi. Jurnal BIODIK. 3 (2), 102-112.

Hayati, S., Budi, A. S. dan Handuko. E. (2015). Pengembangan media pembelajaran flipbook fisika untuk meningkatkan hasil belajar peserta didik. Prosiding Seminar Nasional Fisika, 49-54.

Imaduddin. (2015). Pengembangan LKPD digital berbasis saintifik approach pada materi ekosistem untuk siswa kelas VII SMP. Skripsi Universitas Jambi

Rasiman \& Pramasdyahsari, A.S., (2014). Pengembangan pembelajaran matematika media e-comic berbasis flipbook maker untuk meningkatkan keterampilan berpikir kristis dan karakter siswa SMP. Internasional Journal of Pendidikan dan Penelitian, 2(11), 535-544.

Sadikin, A. (2017). Pengaruh penerapan strategi pembelajaran Rotating Trio Exchange terhadap hasil belajar mata kuliah Dasar - Dasar dan Proses Pembelajaran Biologi. Jurnal BIODIK, 3(2), 74-82. 
Sadikin, A. (2018). Penerapan jurnal belajar untuk meningkatkan motivasi belajar mahasiswa pada mata kuliah Dasar - Dasar dan Proses Pembelajaran Biologi. Bioeducation Journal, 2(1), 70-75.

Salisbury, F.B., \& Cleon W. Ross, (1995). Fisiologi tumbuhan jilid 3. Terjemahan Diah R. Lukman dan Sumaryono, Bandung: ITB.

Wijayanto \& Zuhri, M.S. (2015). Pengembangan e-modul berbasis flip book maker dengan model project based learning untuk mengembangkan kemampuan pemecahan masalah matematika. http://prosiding.upgrismg.ac.id.

Lee, W. \& Owens, D, L. (2004). Multimedia Based Instructional Design, Second Edition. United States of America: John Wiley \& Sonc, Inc..

Zaharah, Yelianti. U \& Asra. R. (2017). pengembangan modul elektronik dengan pendekatan saintifik materi sistem peredaran darah pada manusia untuk siswa kelas VIII. Edusains 6 (1), 26-34.. 